\title{
Overexpression of potassium channel ether à go-gol in human osteosarcoma
}

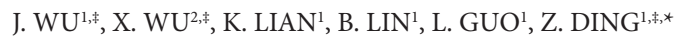 \\ ${ }^{1}$ Department of Orthopaedics, the Affiliated Southeast Hospital of Xiamen University, Orthopaedic Trauma Center of PLA, Zhanghua Road 269, \\ Zhangzhou, Fujian, 363000, the People's Republic of China; ${ }^{2}$ Department of Neurology, the Affiliated Southeast Hospital of Xiamen University, \\ Zhanghua Road 269, Zhangzhou, Fujian, the People's Republic of China
}

${ }^{*}$ Correspondence: zhenqiding175th@yahoo.com.cn

${ }^{*}$ Contributed equally to this work.

\section{Received September 12, 2011 / Accepted October 10, 2011}

\begin{abstract}
Human ether à go-go (hEAG) potassium channels are primarily expressed in brain but also frequently overexpressed in solid tumors, which could indicate their potential value for cancer diagnosis and therapy. hEAG1, one member of the hEAG subfamily, has been shown to play a role in neoplastic process. Here we report the expression of hEAG1 in human osteosarcoma detected by a new polyclonal antibody. The full-length hEAG1 cDNA was cloned from human osteosarcoma cell line MG63 by RT-PCR and expressed in Escherichia coli as His tagged protein. The 6His-hEAG1F protein was purified by nickel agarose and used as the antigen to immunize rabbits following standard protocols. The obtained antiserum could detect hEAG1 exogenously expressed in HEK 293 cells. Furthermore, the polyclonal antibody was used to evaluate hEAG1 expression in 42 human osteosarcoma specimens and 19 osteochondromas specimens by immunohistochemistry. hEAG1 was expressed in 71.4\% (30/42) osteosarcoma, and 15.8\% (3/19) osteochondromas. Moreover, statistical analysis revealed that hEAG1 expression was not dependent on age, sex, site, histology, grade and type in the osteosarcoma specimens. Our data provide evidence that hEAG1 is overexpressed in human osteosarcoma and the hEAG1 polyclonal antibody offers a good tool for further characterization of the oncogenic function of hEAG1 in osteosarcoma.
\end{abstract}

Key words: polyclonal antibody, human potassium channel ether à go-go1, human osteosarcoma, immunohistochemistry

Recently, aberrant expression of voltage-gated $(\mathrm{Kv})$ potassium channels has been detected in many tumors, especially Ether à go-go (EAG) channels have been shown to be linked to neoplastic process. EAG channels were originally cloned from Drosophila melanogaster (1) and formed by three subfamilies: EAG, ERG (the eag-related gene) and ELK (the eag-like gene) (2). These three subfamilies are differentially expressed in different species, including rat, bovine and human (3). Human EAG (hEAG) comprises two independent genes: hEAG1 (Kv10.1) and hEAG2 (Kv10.2). hEAG1 was first described as a cell-cycle regulated channel (4). Recent data show that hEAG1 has a restricted distribution in the central nervous system (5) and is expressed transiently in myoblasts (6), yet ectopic hEAG1 expression indicated its potential role in tumor generation and progression. hEAG1 has been proposed as a marker of tumors since its expression level is significantly different between tumors and the matched normal tissues (5). Additionally, hEAG1 has been suggested as being important for tumor cell proliferation. Antisense experiments against
hEAG1 or hEAG1-RNA silencing suppressed cell proliferation in some cancer cell lines (7). Finally, aberrant expression of hEAG1 is associated with poor prognosis in a range of tumors $(7,8)$. These studies strongly suggest that hEAG1 represents a potential target for cancer diagnosis, treatment, and prognosis $(8,9)$.

Osteosarcoma is the most common malignant primary bone tumor (10-12). It has a high metastatic potential, most commonly spreading to the lung and bone (13). The relatively high mortality of osteosarcoma is predominantly associated with systemic metastasis, especially the pulmonary metastasis (14). Despite aggressive treatment modalities, such as high-dose chemotherapy and wide tumor resection, the patient's 5-year survival rate is only $55 \%-60 \%$, and even less than $40 \%$ with pulmonary metastasis (15). Meanwhile, high-dose chemotherapy has lots of adverse reactions such as gastrointestinal reactions, bone marrow suppression, cardiac toxicity, renal toxicity, which restrict the application of chemotherapy. Additionally, studies suggested that high-dose chemotherapy for several years could 
easily cause malignant tumors in other parts of the body, such as leukemia, breast cancer, lung cancer, and central nervous system tumors (16). Thus the development of new treatments for osteosarcoma has become an urgent clinical need.

Although the clear involvement of hEAG1 in proliferation and tumor progression, so far little attention has been drawn to the relationship between hEAG1 and human osteosarcoma. The biological activities and functions of hEAG1 in human osteosarcoma cells have remained a mystery. It is hypothesized that the high expression of hEAG1 contributes to tumor proliferation and progression. To address this question, we report here the preparation and identification of a new polyclonal antibody for hEAG1, and its preliminary application in the evaluation of hEAG1 expression in clinical osteosarcoma samples.

\section{Materials and methods}

Cell culture and cell transfection. Human osteosarcoma cell line MG63 and human embryonic kidney 293 (HEK 293) were purchased from the American Type Culture Collection, and cultured in RPMI-1640 medium supplemented with 10\% fetal bovine serum, $100 \mathrm{IU} / \mathrm{ml}$ penicillin, $100 \mu \mathrm{g} / \mathrm{ml}$ streptomycin in a humidified atmosphere in $5 \% \mathrm{CO}_{2}$ and $95 \%$ air at $37^{\circ} \mathrm{C}$. HEK 293 cells were seeded in a 6-well culture plate, and then grown to $50-70 \%$ confluence. Cells were washed with $\mathrm{PBS}$, and $1.5 \mathrm{ml}$ serum-free medium was added to each well. pcDNA3.1(+), pcDNA3.1-hEAG1, or pcDNA3.1-hEAG2 was transfected transiently into HEK 293 cells using Lipofectamine 2000 (Invitrogen, USA) according to the manufacturer's instructions. After incubation for $6 \mathrm{~h}$, each dish was replaced with $2 \mathrm{ml}$ complete medium and incubated for $48 \mathrm{~h}$. The cells were harvested and lysed in cell lysis buffer $(20 \mathrm{mM}$ Tris-HCl, pH 7.5, $150 \mathrm{mM} \mathrm{NaCl}, 1 \mathrm{mM} \mathrm{Na} 2$ EDTA, $1 \mathrm{mM}$ EGTA, 1\% Triton X-100, $2.5 \mathrm{mM}$ sodium pyrophosphate, 1 $\mathrm{mM} \beta$-glycerophosphate, $1 \mathrm{mM} \mathrm{Na}_{3} \mathrm{VO}_{4}$ containing proteinase inhibitors). Other cells were treated for immunofluorescence analysis.

RT-PCR. Total RNA was isolated from the cultured MG63 cells by Trizol reagent (TaKaRa, Japan), and cDNA was synthesized from $1 \mu \mathrm{g}$ total RNA using $200 \mathrm{U}$ reverse transcriptase, plus $200 \mu \mathrm{M}$ dNTPs and $2.5 \mu \mathrm{M}$ oligo-dT primer, in a $20 \mu \mathrm{l}$ reaction volume, at $30^{\circ} \mathrm{C}$ for $10 \mathrm{~min}, 42^{\circ} \mathrm{C}$ for $1 \mathrm{~h}$, and finally at $80^{\circ} \mathrm{C}$ for $5 \mathrm{~min} .1 \mu \mathrm{l} \mathrm{cDNA}$ were then amplified by polymerase chain reaction (PCR) in $25 \mu \mathrm{l}$ reaction, containing DNA polymerase $2.5 \mathrm{U}, 200 \mu \mathrm{M}$ dNTPs, polymerase reaction buffer and the primers. The $h E A G 1$ full length primers for eukaryotic expression were 5'GGG GTA CCA TGA CCA TGG CTG GGG GCA GGA GG3' (forward primer containing a KpnI site) and 5'CCC TCG AGT CAG CTG GCT CCA AAA ATG TCT CT3' (reverse primer containing an XhoI site), and the $h E A G 1$ fragment $(h E A G 1 F)$ primers for prokaryotic expression were 5'CCC TCG AGA TGC TAG GAA AAG GAG ACG TGT TT3' (forward primer containing an XhoI site) and 5'GGG TAC CTC AGC TGG CTC CAA AAA TGT C3' (reverse primer containing a KpnI site). PCR was performed under the following conditions: $5 \mathrm{~min}$ at $95^{\circ} \mathrm{C}$ for denaturation, then 30 s at $95^{\circ} \mathrm{C}, 1 \mathrm{~min}$ at $50^{\circ} \mathrm{C}, 3 \mathrm{~min}$ at $72^{\circ} \mathrm{C}$ for 35 circles, and 10 min at $72^{\circ} \mathrm{C}$ for an additional extension. The amplified product was cloned into pGEM-T easy vector (Promega, USA) to make pGEM-T-hEAG1 (full length hEAG1) and pGEM-T-hEAG1F (hEAG1 fragment) recombinant vectors. Positive clones were selected and sequenced by Sangon (Shanghai, China).

Construction of expression vectors. After digestion of pGEM-T-hEAG1 with KpnI/XhoI, the purified product was inserted into pcDNA3.1(+) vector (Invitrogen, USA) and confirmed by restriction analysis. The correct recombinant vector was named pcDNA3.1-hEAG1. Similarly, hEAG2 fragment was cloned into pcDNA3.1(+) and named pcDNA3.1-hEAG2. In addition, hEAG1 fragment was cloned into the prokaryotic expression vector and named pRSET-A-hEAG1F.

Expression and purification of the 6His-hEAG1F fusion protein. The prokaryotic expression vector pRSET-A-hEAG1F was transformed into the bacteria host E. coli BL21 (DE3) following standard protocol. $10 \mathrm{ml}$ bacteria was inoculated into $200 \mathrm{ml} \mathrm{LB}$ medium and cultured until the optic density (OD) reached 0.6 at $600 \mathrm{~nm}$, when isopropyl-1-thio-D-galactopyranoside (IPTG) was added to a final concentration of $1 \mathrm{mM}$ to induce the protein expression for $4 \mathrm{~h}$ at $37^{\circ} \mathrm{C}$. Cells were collected by centrifugation at $8,000 \mathrm{~g}$ for $15 \mathrm{~min}$ at $4^{\circ} \mathrm{C}$. The pellets were suspended in $10 \mathrm{ml}$ of buffer $\mathrm{B}$ ( $8 \mathrm{M}$ urea; 0.1 $\mathrm{M} \mathrm{NaH}_{2} \mathrm{PO}_{4} ; 0.01 \mathrm{M}$ Tris.Cl; $\mathrm{pH} 8.0$ ), incubated for $30 \mathrm{~min}$ at $37^{\circ} \mathrm{C}$, and sonicated on ice. After centrifugation at $16,000 \mathrm{~g}$ for $15 \mathrm{~min}$, the suspension was loaded onto the Ni-nitrilotriacetic acid (Ni-NTA) agarose (Qiagen, Germany) at $4^{\circ} \mathrm{C}$ for $1 \mathrm{~h}$. Then, the agarose was poured into a column and washed with $30 \mathrm{ml}$ buffer $\mathrm{C}$ (containing $8 \mathrm{M}$ urea; $0.1 \mathrm{M} \mathrm{NaH}_{2} \mathrm{PO}_{4} ; 0.01$ $\mathrm{M}$ Tris.Cl; $\mathrm{pH}$ 6.3). Finally, the column was eluted with $5 \mathrm{ml}$ buffer $\mathrm{E}$ (containing $8 \mathrm{M}$ urea; $0.1 \mathrm{M} \mathrm{NaH}_{2} \mathrm{PO}_{4} ; 0.01 \mathrm{M}$ Tris.Cl; $\mathrm{pH}$ 4.5). The recombinant 6 His-hEAG1F was dialyzed with PBS (pH 7.4).

Generation and purification of hEAG1 antibody. The purified 6 His-hEAG1F protein was used to generate antibodies in a New Zealand white rabbit. A total of four injections of $1.6 \mathrm{mg} 6 \mathrm{His}-\mathrm{hEAG} 1 \mathrm{~F}$ protein in Freund's adjuvant (Sigma, USA) were performed at day $0,14,28$ and 56 before final bleeding at day 80 . The rabbit IgG fraction was precipitated from the immune serum with $50 \%$ saturated $\left(\mathrm{NH}_{4}\right)_{2} \mathrm{SO}_{4}$ and purified by DEAE-Sepharose column chromatography. The titer of purified polyclonal antibody was determined by an ELISA assay using purified $6 \mathrm{His}-\mathrm{hEAG} \mathrm{F}$ and carrier proteins coated onto microplate. The antibody at different dilutions (200 to 25,600 fold) was incubated with an equal amount of the fusion protein $(5 \mu \mathrm{g})$. The anti-His antibody was used as a positive control. The pre-immunized rabbit serum served as a negative control.

Western blot analysis. Proteins were separated by $10 \%$ SDS-PAGE and electro-transferred to PVDF membranes. The membranes were incubated overnight at $4^{\circ} \mathrm{C}$ with either hEAG1 polyclonal antibody we generated $(1: 1000)$ or hEAG2 
antibody (SAB2104244, Sigma, USA) in blocking solution, then with horseradish peroxidase (HRP) conjugated goat anti-mouse antibody $(1: 10,000)$ or goat anti-rabbit antibody $(1: 15,000)$, and finally developed by enhanced chemiluminescence system. Moreover, Western blot analysis was also used to test the immunoreacitivity of hEAG1 polyclonal antibody we generated and commercial hEAG1 antibody (APC-104, Alomone Labs, Israel, 1:200) performed on protein extracts obtained from mouse brain, a tissue highly expressing hEAG1 protein.

Immunofluorescence assay. HEK 293 cells were washed with cold PBS, and fixed with $1.5 \mathrm{ml} 4 \%$ paraformaldehyde in PBS for $30 \mathrm{~min}$. The cells were then washed with cold PBS and incubated with $10 \%$ normal goat serum for 45 min to block non-specific binding, then incubated with the generated hEAG1 polyclonal antibody (diluted 1:50 with PBS ) overnight at $4^{\circ} \mathrm{C}$. The cells were then washed three times with PBS and subsequently incubated with rhodamine-conjugated goat anti-rabbit IgG for $30 \mathrm{~min}$ at $37^{\circ} \mathrm{C}$. The nucleus was detected by incubation with 4 , 6'-diamidino-2-phenylindole (DAPI, $1 \mu \mathrm{g} / \mathrm{ml}$ ) for $15 \mathrm{~min}$. Background staining was examined by use of the secondary antibody alone. The slides were mounted in 50\% (v/v) glycerol-PBS and photographed by Zeiss fluorescent microscope.

Sample collection. A total of 61 formalin-fixed, paraffinembedded specimens, including 42 osteosarcomas from 26 patients (before the administration of neoadjuvant chemotherapy) and 19 osteochondromas from 19 patients were acquired from the affiliated Southeast Hospital of Xiamen University between January 2005 and June 2009, with complete clinicopathologic parameters. As a positive control sample (5) of healthy human brain obtained from biopsy was used. All the specimens were incorporated in the study after obtaining written informed consent according to a protocol approved by Institutional Review Board of the affiliated Southeast Hospital of Xiamen University.

Immunohistochemical staining. The tissue slide was baked on a rack in a dry oven at $60^{\circ} \mathrm{C}$ for $2 \mathrm{~h}$ to remove the coated paraffin. The samples were demineralized with an equal parts mixture of $20 \%$ sodium citrate and $45 \%$ formic acid. The slide was immersed twice in xylene for $3 \mathrm{~min}$, hydrated with $100 \%$, 95\%, 70\% and 50\% ethanol and rinsed with cold tap water for $5 \mathrm{~min}$. After dewaxing and blocking endogenous peroxidases, the sections were treated at $100^{\circ} \mathrm{C}$ in EDTA $(1 \mathrm{mM}, \mathrm{pH} 8.0)$ for antigen retrieval, and then incubated with hEAG1 polyclonal antibody (1:100) overnight at $4^{\circ} \mathrm{C}$. The slides were washed with PBS and incubated with biotinylated goat anti-rabbit IgG at room temperature for $1 \mathrm{~h}$. Diaminobenzamidine (DAB) was used to visualize the tissue slide and the sections were counterstained with haematoxylin. Samples were defined as positive when more than $10 \%$ of the cells stained positive with the hEAG1 polyclonal antibody similar to previously reported (17).

Statistical analysis. All statistical analyses were performed using SPSS16.0 software. The differences between groups were compared using $\chi^{2}$-test. Statistical difference was accepted at $\mathrm{P}<0.05$.

\section{Results}

Construction of hEAG1 expression vectors. The complete cDNA of $h E A G 1$ was amplified by RT-PCR from the MG63 cells using specific primers designed according to the published sequence of hEAG1 (GenBank accession No. AF078741). Full length $h E A G 1$ cDNA was cloned into the pGEM-T Easy vector and confirmed by DNA sequencing with no any mutation detected. Then the hEAG1 was subcloned into pcDNA3.1(+) to make pcDNA3.1-hEAG1 vector for the expression in eukaryotic cells.

$h E A G 1$ fragment $(h E A G 1 F)$ encoding for the intracellular domain of hEAG1 (from 640 aa to 988 aa, based on amino acid sequence analysis using the TMHMM Server (http://www. cbs.dtu.dk/services/TMHMM/) was PCR amplified and subcloned into pRSET-A to make pRSET-A-hEAG1F vector for the expression in bacteria.

Expression and purification of the recombinant $6 \mathrm{His}-$ tagged hEAG1 protein. Western blot using His antibody demonstrated that a predicted band of $44 \mathrm{kDa}$ representing recombinant 6 His-hEAG1F protein in the cell lysates of BL21(DE3) carrying pRSET-A-hEAG1F after induction with $1 \mathrm{mM}$ IPTG (data not show). Thus we made a largescale induction of recombinant protein in BL21(DE3) harboring pRSET-A-hEAG1F and purified the recombinant 6 His-hEAG1F by Ni-NTA agarose. The purified protein was run as a single band about $44 \mathrm{kDa}$ on $10 \%$ SDS-PAGE (Fig. 1). After dialysis in PBS, the purified protein was quantified to be $210 \mu \mathrm{g} / \mathrm{mL}$ by Lowry method.

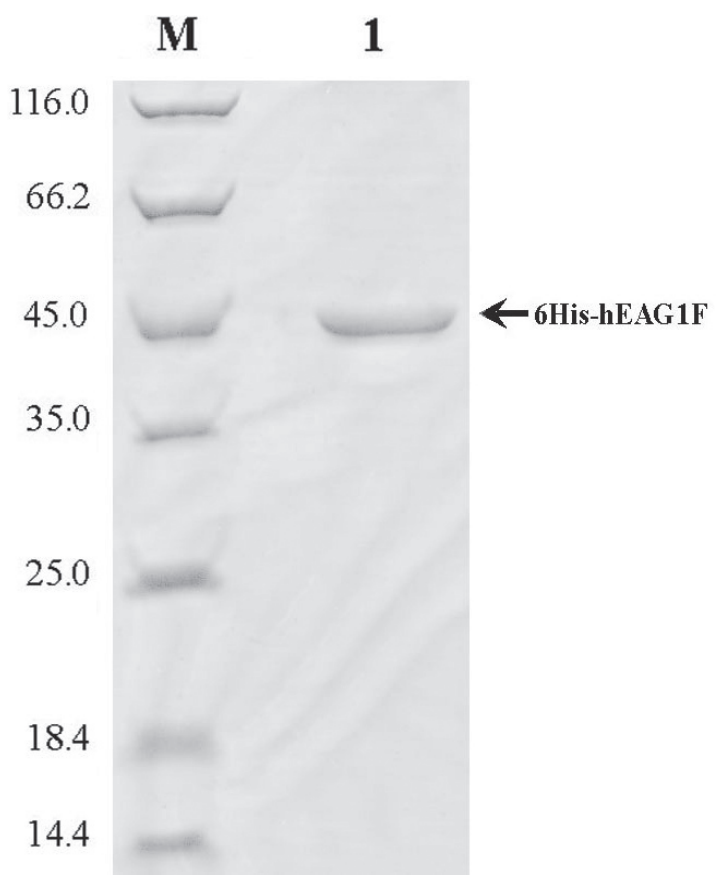

Figure 1. Purified 6His-hEAG1F run on $10 \%$ SDS-PAGE. M: marker; 1: 6His-hEAG1F purified by Ni-NTA agarose. 

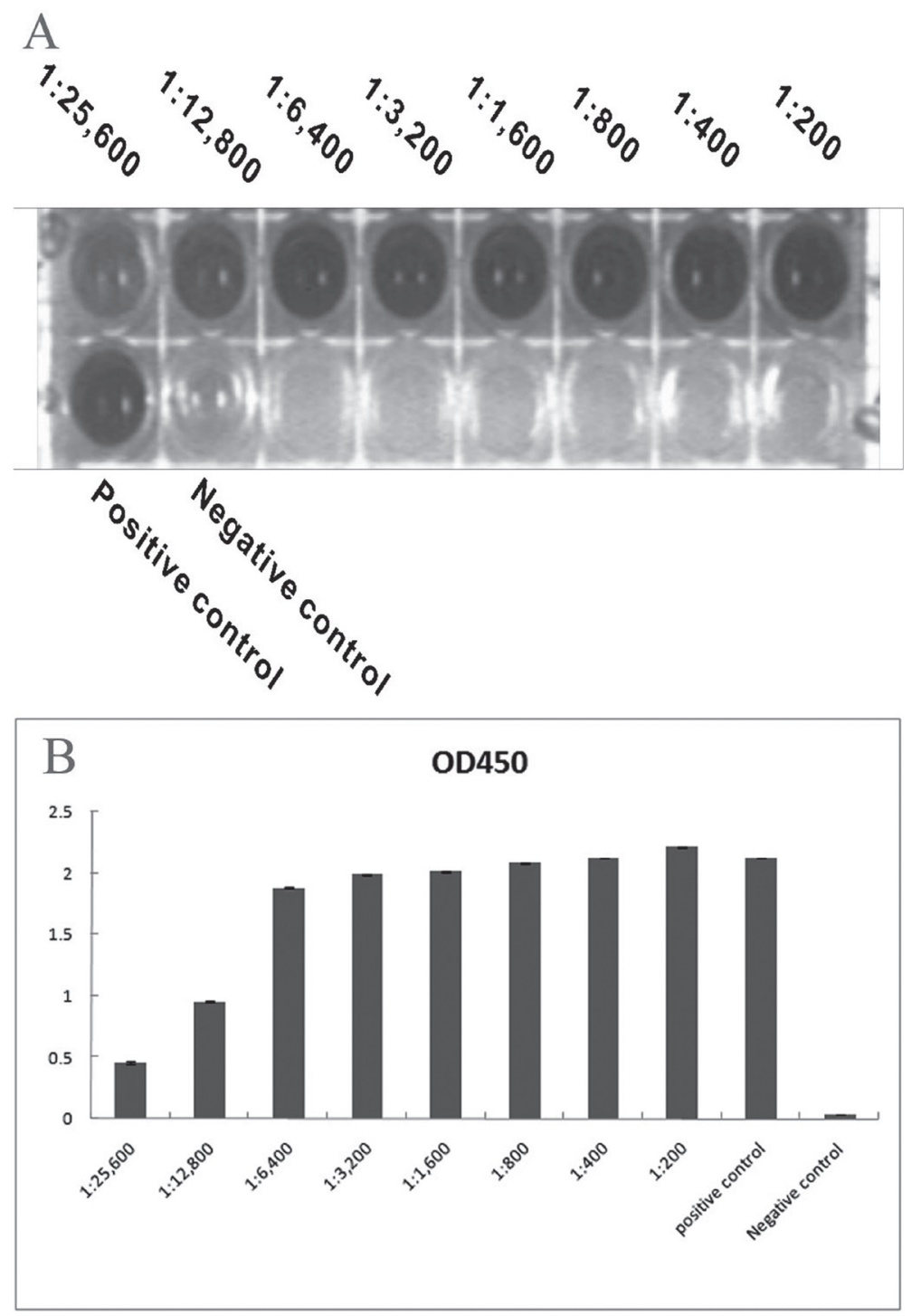

Figure 2. Determination of the titer of hEAG1 polyclonal antibody by ELISA.

(A) The antibody was diluted serially as shown on the top. Positive control was anti-His antibody; Negative control was pre-immunized rabbit serum. (B) Quantization of absorbance values shown in Fig. 2A.

Generation and characterization of hEAG1 polyclonal antibody. New Zealand white rabbits were immunized by an intraperitoneal injection of $400 \mu \mathrm{g}$ purified recombinant 6 HishEAG1F emulsified with an equal volume of Freund's complete adjuvant. The activity of purified antibody was evaluated by ELISA, which showed that the titer of hEAG1 polyclonal antibody was higher than 1:25,600 (Fig. 2).

In addition, Western blot analysis showed that hEAG1 polyclonal antibody could detect both hEAG1 fragment expressed in E. coli and full-length hEAG1 expressed in HEK293 cells (Fig. 3A). Given that Eag2 shares the highest homology to Eag1 with about $73 \%$ identity (18), we examined the specificity of hEAG1 polyclonal antibody against
hEAG2. Western blot results showed that hEAG1 polyclonal antibody could only detect hEAG1 but not hEAG2 transiently expressed in HEK293 cells (Fig. 3B). Furthermore, the immunoreactivity of hEAG1 polyclonal antibody we generated was compared with commercial hEAG1 antibody (specific for hEAG1, not crossreact with hEAG2). The results showed that the polyclonal antibody we generated was better to detect hEAG1 than commercial hEAG1 antibody because no unspecific bands were detected (Fig. 4, compare lane 1 and lane 2). Finally, we evaluated the application of hEAG1 polyclonal antibody in immunofluorescence assays and found that hEAG1 was expressed in the cell cytoplasm, predominantly the perinuclear cytoplasm (Fig. 5). While hEAG1 is 
A

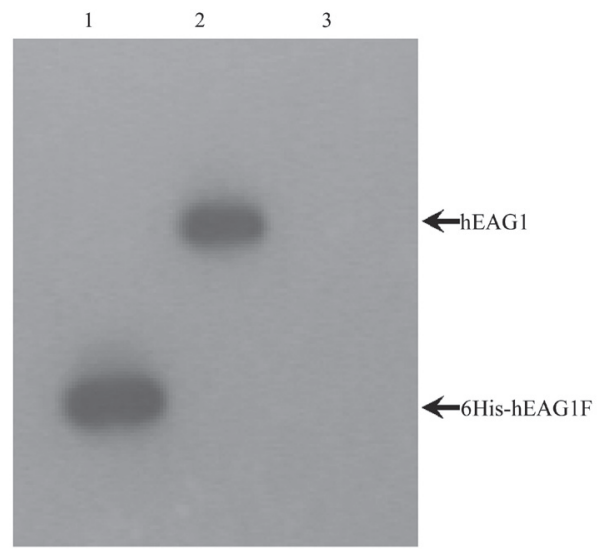

B

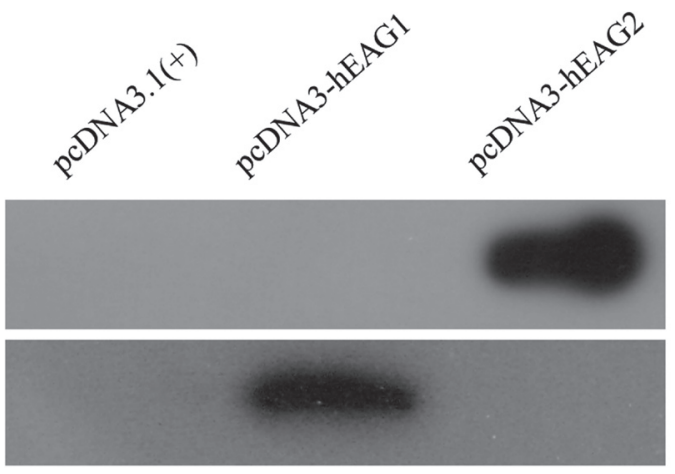

Anti-hEAG2

Anti-hEAG1

Figure 3. Analysis of the activity and specificity of hEAG1 polyclonal antibody by Western blot.

(A) Western blot showing the activity of hEAG1 polyclonal antibody. Lane 1, lysate of $E$. coli BL21(DE3) cells harboring pRSET-AhEAG1F after induction; Lane 2, lysate of HEK 293 cells transfected by pcDNA3.1-hEAG1; Lane 3, lysate of HEK 293 cells transfected by pcDNA3.1(+) empty vector. (B) Western blot showing the specificity of hEAG1 polyclonal antibody. Lysate of HEK293 cells transfected by pcDNA3.1 empty vector, pcDNA3.1-hEAG1 or pcDNA3.1-hEAG2 was detected by the indicated antibodies.

definitely a transmembrane protein, previous studies have reported similar findings that immunostaining of hEAG1 is preferentially cytoplasmic with predominant perinuclear localization $(7,19)$, perhaps due to the functional hEAG1 localizes to the inner nuclear membrance (20). Taken together, these data prove that we have generated hEAG1 polyclonal antibody with high activity and specificity, which could be used for further characterization of hEAG1 expression patterns and function.

Clinical parameters of specimens. The clinical parameters of 42 osteosarcoma specimens were shown in Table 1. Twentyfour (57.1\%) males and 18 (42.9\%) females with mean age (M \pm SD) of $21.42 \pm 11.36$ years (range 9-63 years) were enrolled in this study. Twenty-seven (64.3\%) tumors originated in the femur, $10(23.8 \%)$ in the tibia and $5(11.9 \%)$ in other site.

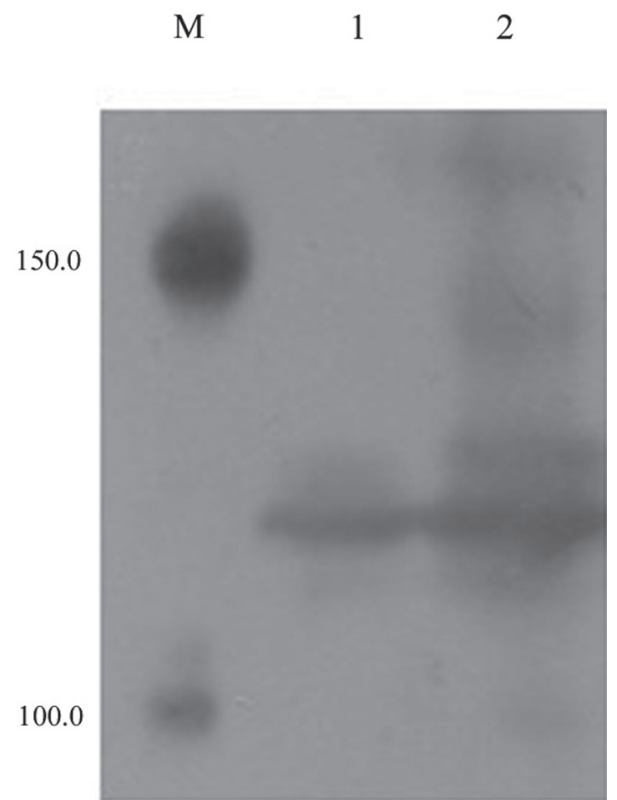

Figure 4. Analysis of the immunoreactivity of hEAG1 antibodies by Western blot.

Mouse brain extracts were prepared, separated on SDS-PAGE and transferred on PVDF membrane as described in Materials. Membranes were immunolabelled with the polyclonal antibody we generated (diluted 1:1000, lane 1), or with the commercial hEAG1 antibody (diluted 1:200, lane 2). The bands revealed by both antibodies had a molecular weight between 150 and $100 \mathrm{kDa}$. M: marker.

Histologically, the most common subtype was osteoblastic osteosarcoma (42.8\%), followed by chondroblastic osteosarcoma (23.8\%) and fibroblastic osteosarcoma (16.7\%). Nine patients were low-grade osteosarcoma (21.4\%), and 33 patients were high-grade osteosarcoma (78.6\%). There were $34(81.0 \%)$ primary osteosarcoma and $8(19.0 \%)$ recidivating osteosarcoma. The remaining 19 specimens including 12 (63.2\%) males and $7(36.8 \%)$ females were diagnosed as osteochondroma. The median age was 16.47 years in patients with osteochondromas (range 5-43 years).

Overexpression of hEAG1 in human osteosarcoma specimens. hEAG1 polyclonal antibody was employed for immunohistochemical staining of hEAG1 in human osteosarcoma and osteochondroma samples. Positive hEAG1 staining was detected in 30/42 (71.4\%) osteosarcoma and $3 / 19(15.8 \%)$ osteochondromas. The positive signal was detected mainly in perinuclear cytoplasm, consistent with previous reports $(7,19)$. As a control, hEAG1 staining was detected in a normal human brain sample. A representative case of each category was in Fig. 6. Statistical analysis indicated that positive expression of hEAG1 in human osteosarcoma and osteochondroma was significantly different $(\mathrm{P}<0.05)$, but no association was detected between hEAG1 expression and any clinicopathologic parameters in the 42 osteosarcoma specimens (Table 1). 


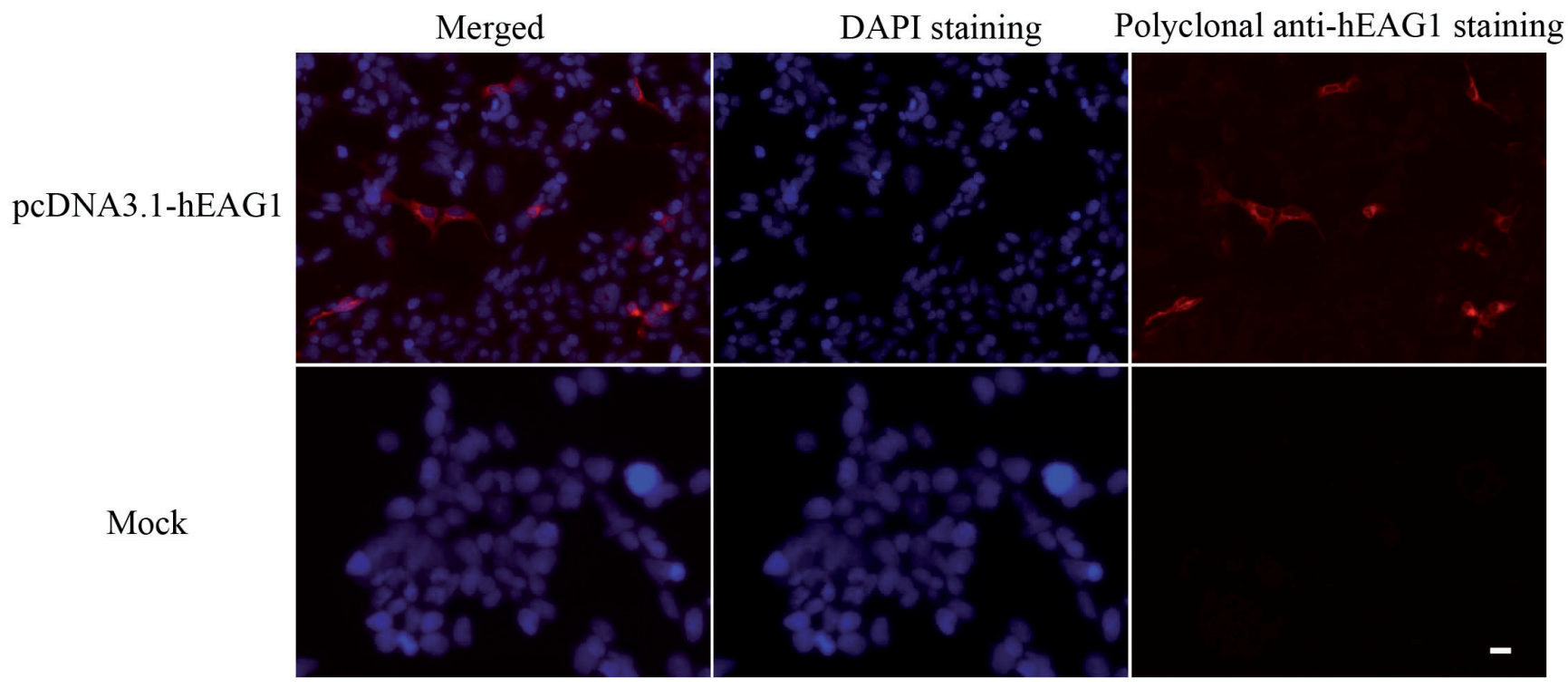

Figure 5. Immunofluorescence analysis of hEAG1 subcellular localization by hEAG1 polyclonal antibody.

HEK293 cells were either mock transfected with pcDNA3.1(+) or transfected with pcDNA3-hEAG1, and then stained with hEAG1 polyclonal antibody. Positive hEAG1 staining was red and DAPI (indicating the nucleus) was blue. The scale bar: $10 \mu \mathrm{m}$.
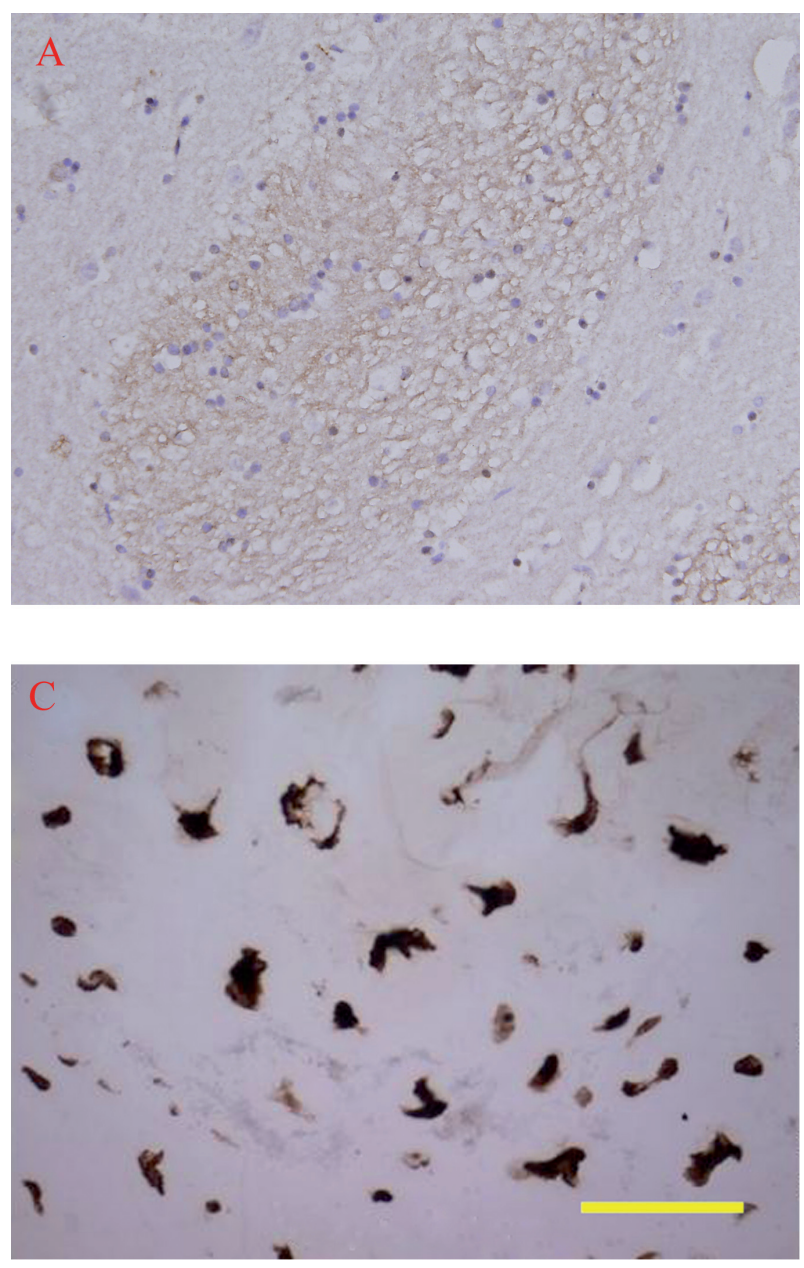

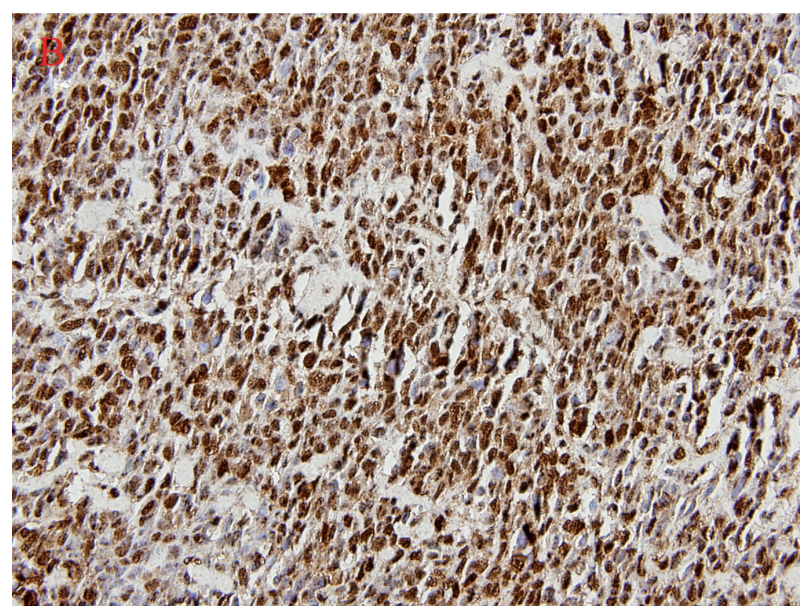

Figure 6. Immunohistochemical staining of hEAG1 in human osteosarcoma samples.

hEAG1 immunostaining was detected in a human brain specimen (positive control, A) , 71.4\% of human osteosarcoma specimens (B) and $(15.8 \%)$ osteochondromas specimens (C). Images were captured using an $\mathrm{OL}$ YMPUS light microscope equipped with a CCD colour camera at a $400 \times$ magnification. The scale bar: $50 \mu \mathrm{m}$. 
Table 1. Clinical Parameters of osteosarcoma specimens and hEAG1 expression

\begin{tabular}{|c|c|c|c|c|}
\hline $\begin{array}{c}\text { Clinical Parameters } \\
\text { of Samples }\end{array}$ & $\begin{array}{l}\text { Number of } \\
\text { Tumors (\%) }\end{array}$ & $\begin{array}{c}\text { hEAG1 } \\
\text { expression (\%) }\end{array}$ & $\chi^{2}$ value & $\mathrm{P}$ \\
\hline Sex & & & 0.350 & 0.554 \\
\hline Male & $24(57.1 \%)$ & $18(75.0 \%)$ & & \\
\hline Female & $18(42.9 \%)$ & $12(66.7 \%)$ & & \\
\hline Age (year) & & & 2.378 & 0.498 \\
\hline$\leq 12$ & $10(23.8 \%)$ & $8(80.0 \%)$ & & \\
\hline $13-20$ & $18(42.9 \%)$ & $14(77.8 \%)$ & & \\
\hline $21-30$ & $8(19.0 \%)$ & $5(62.5 \%)$ & & \\
\hline$>31$ & $6(14.3 \%)$ & $3(50.0 \%)$ & & \\
\hline Site & & & 0.913 & 0.634 \\
\hline Femur & $27(64.3 \%)$ & $20(74.1 \%)$ & & \\
\hline Tibia & $10(23.8 \%)$ & $6(60.0 \%)$ & & \\
\hline Other & $5(11.9 \%)$ & $4(80.0 \%)$ & & \\
\hline Histology & & & 2.186 & 0.702 \\
\hline Osteoblastic & $18(42.8 \%)$ & $14(77.8 \%)$ & & \\
\hline Chondroblastic & $10(23.8 \%)$ & $8(80.0 \%)$ & & \\
\hline Telangetatic & $2(4.8 \%)$ & $1(50.0 \%)$ & & \\
\hline Fibroblastic & $7(16.7 \%)$ & $4(57.1 \%)$ & & \\
\hline Other & $5(11.9 \%)$ & $3(60.0 \%)$ & & \\
\hline Grade & & & 0.226 & 0.634 \\
\hline Low-Grade & $9(21.4 \%)$ & $7(77.8 \%)$ & & \\
\hline High-Grade & $33(78.6 \%)$ & $23(69.7 \%)$ & & \\
\hline Type & & & 0.386 & 0.534 \\
\hline Primary & $34(81.0 \%)$ & $25(73.5 \%)$ & & \\
\hline Recurrence & $8(19.0 \%)$ & $5(62.5 \%)$ & & \\
\hline Total & 42 & $30(71.4 \%)$ & & \\
\hline
\end{tabular}

\section{Discussion}

hEAG1 has drawn intense attention in the field of oncology for several reasons. First, this membrane protein is accessible from the extracellular side and is aberrantly expressed in many types of tumors such as gastric cancers (21), colon carcinoma (22) and renal cell carcinoma (23), but negatively expressed in non-cancerous matched tissues. Second, inhibition of the expression of hEAG1 or EAG-mediated currents by different experimental methods suppressed cell proliferation $(7,24,25)$. Third, the latest literatures have confirmed that aberrant expression of hEAG1 in tumors is associated with poor prognosis $(26,27)$. Therefore, hEAG1 has emerged as a promising target for the detection and therapy of different tumors $(28,29)$.

For the detection of hEAG1 in clinical samples, it is very important to develop highly active and specific antibody. While several hEAG1 antibodies are currently commercially available, most of them are monoclonal antibodies directed against short hEAG1 peptides. In addition, several bands at the expected size of hEAG1 are frequently detected by Western blot with these antibodies. For these reasons, we have decided to develop hEAG1 polyclonal antibody with high activity and specificity to facilitate the investigation of hEAG1 function in tumorigenesis and its immunoreactivity was better than the commercial hEAG1 antibody widely used.

We expressed hEAG1 fragment as a His tagged protein in E. coli to facilitate the purification by Ni-NTA agarose. Next we used the purified hEAG1 protein as the antigen to immunize rabbits and generated polyclonal antibody. ELISA and Western blot demonstrated that we got highly specific and sensitive hEAG1 polyclonal antibody. Notably, we detected a single band of hEAG1 in Western blot by using the antibody we generated, in contrast to multiple bands detected using other antibodies as reported previously. This may be due to the fact that we transfected full-length hEAG1 cDNA construct into HEK 293 cells and potentially avoided the splicing of hEAG1 mRNA or the posttranslational modification or degradation of hEAG1. Therefore, we detected the fully mature hEAG1 protein. Furthermore, we employed the hEAG1 antibody in immunocytochemical and immunohistochemical assays. The results proved that the antibody is sensitive and specific for the detection of hEAG1 expression in the transfected HEK 293 cells and clinical samples. Our data provide evidence that hEAG1 is expressed in primary malignant bone tumors with a higher frequency as compared to benign bone tumors. However, the expression of hEAG1 was not correlated with any clinicopathological features of os- 
teosarcoma in this study. Although many prognostic markers have been examined in osteosarcoma, their prognostic and therapeutic relevance remain doubtful. A relevant question to approach in further experiments is to assess whether the prognostic value of hEAG1 in other tumors is applicable to osteosarcoma and this will be our next aim.

Acknowledgments: This study was supported by Fujian Natural Science Foundation, China (No. C0710048). We also sincerely thank Professor Luis A. Pardo (Max-Planck Institute for Experimental Medicine, Göttingen, Germany) for his help.

\section{References}

[1] WARMKE J, DRYSDALE R AND GANETZKY B. A distinct potassium channel polypeptide encoded by the Drosophila eag locus. Science 1991; 252: 1560-1562. http://dx.doi. org/10.1126/science.1840699

[2] WARMKE JW AND GANETZKY B. A family of potassium channel genes related to eag in Drosophila and mammals. Proc Natl Acad Sci USA 1994; 91: 3438-3442. http://dx.doi. org/10.1073/pnas.91.8.3438

[3] BAUER CK AND SCHWARZ JR. Physiology of EAG K+ channels. J Membr Biol 2001; 182: 1-15. http://dx.doi. org/10.1007/s00232-001-0031-3

[4] CAMACHO J, SÁNCHEZ A, STÜHMER W AND PARDO LA. Cytoskeletal interactions determine the electrophysiological properties of human EAG potassium channels. Pflugers Arch 2000; 441: 167-174. http://dx.doi.org/10.1007/ $\underline{\text { s004240000420 }}$

[5] FARIAS LM, OCAÑA DB, DÍAZ L, LARREA F, AVILACHÁVEZ E et al. Ether à go-go potassium channels as human cervical cancer markers. Cancer Res 2004; 64: 6996-7001. http://dx.doi.org/10.1158/0008-5472

[6] OCCHIODORO T, BERNHEIM L, LIU JH, BIJLENGA P, SINNREICH M et al. Cloning of a human ether à go-go potassium channel expressed in myoblasts at the onset of fusion. FEBS Lett 1998; 434: 177-182. http://dx.doi.org/10.1016/S00145793(98)00973-9

[7] MELLO DE QUEIROZ F, SUAREZ-KURTZ G, STÜHMER W AND PARDO LA. Ether à go-go potassium channel expression in soft tissue sarcoma patients. Mol Cancer 2006; 5:42. http://dx.doi.org/10.1186/1476-4598-5-42

[8] DING XW, WANG XG, LUO HS, TAN SY, GAO S et al. Expression and prognostic roles of Eag1 in resected esophageal squamous cell carcinomas. Dig Dis Sci 2008; 53: 2039-2044. http://dx.doi.org/10.1007/s10620-007-0116-7

[9] PARDO LA AND SÜHMER W. Eag1 as cancer target. Expert Opin Ther Targets 2008; 12: 837-843. doi:10.1517/14728222.12.7.837 http://dx.doi.org/10.1517/ 14728222.12.7.837

[10] DAMRON TA, WARD WG AND STEWART A. Osteosarcoma, chondrosarcoma, and Ewing's sarcoma: National Cancer Data Base report. Clin Orthop Relat Res 2007; 459: 40-47. http://dx.doi.org/10.1097/BLO.0b013e318059b8c9

[11] SLUGA M, WINDHAGER R, PFEIFFER M, OFNER P, LANG $S$ et al. Osteosarcoma and Ewing's sarcoma-The most frequent malignant bone tumors in children-therapy and outcome. Z Orthop Ihre Grenzgeb 2002; 140: 652-655. http://dx.doi. org/10.1055/s-2002-36040

[12] WITTIG JC, BICKELS J, PRIEBAT D, JELINEK J, KELLARGRANEY K et al. Osteosarcoma: a multidisciplinary approach to diagnosis and treatment. Am Fam Physician 2002; 65: 1123 1132. http://dx.doi.org/10.1016/j.progpolymsci.2008.07.007

[13] LAVERDIERE C, HOANG BH, YANG R, SOWERS R, QIN $J$ et al. Messenger RNA expression levels of CXCR4 correlate with metastatic behavior and outcome in patients with osteosarcoma. Clin Cancer Res 2005; 11: 2561-2567. http://dx.doi. org/10.1158/1078-0043.CCR-04-1089

[14] URAKAWA H, NISHIDA Y, NAKASHIMA H, SHIMOYAMA Y, NAKAMURA $S$ et al. Prognostic value of indoleamine 2,3dioxygenase expression in high grade osteosarcoma. Clin Exp Metastasis 2009; 26: 1005-1012. http://dx.doi.org/10.1007/ $\underline{\text { s10585-009-9290-7 }}$

[15] WU PK, CHEN WM, CHEN CF, LEE OK, HAUNG CK et al. Primary osteogenic sarcoma with pulmonary metastasis: clinical results and prognostic factors in 91 patients. Jpn J Clin Oncol 2009; 39: 514-522. http://dx.doi.org/10.1093/ijco/ $\underline{\text { hyp057 }}$

[16] SAKAMOTO A AND IWAMOTO Y. Current status and perspectives regarding the treatment of osteosarcoma: chemotherapy. Rev Recent Clin Trials 2008; 3: 228-231. http://dx.doi. org/10.2174/157488708785700267

[17] MATSUURA N, OHNISHI A, ITOH Y, WAKASUGI E and TSUJIMOTO M. Immunohistochemistry in the diagnosis and treatment of breast cancer. Gan To Kagaku Ryoho 1996; 23: 24-29.

[18] LUDWIG J, WESELOH R, KARSCHIN C, LIU Q, NETZER $\mathrm{R}$ et al. Cloning and functional expression of rat eag2, a new member of the ether-à-go-go family of potassium channels and comparison of its distribution with that of eag1. Mol Cell Neurosci 2000; 16: 59-70. http://dx.doi.org/10.1006/ mone.2000.0851

[19] HEMMERLEIN B, WESELOH RM, MELLO DE QUEIROZ F, KNÖTGEN H, SÁNCHEZ A et al. Overexpression of Eag1 potassium channels in clinical tumours. Mol Cancer 2006; 5: 41. http://dx.doi.org/10.1186/1476-4598-5-41

[20] CHEN Y, SÁNCHEZ A, RUBIO ME, KOHL T, PARDO LA et al. Functional K(v)10.1 channels localize to the inner nuclear membrane. PLoS One 2011; 6: e19527. http://dx.doi. org/10.1371/journal.pone.0019257

[21] DING XW, LUO HS, JIN X, YAN JJ AND AI YW. Aberrant expression of Eag1 potassium channels in gastric cancer patients and cell lines. Med Oncol 2007; 24: 345-350. http://dx.doi. org/10.1007/s12032-007-0015-y

[22] OUSINGSAWAT J, SPITZNER M, PUNTHEERANURAK S, TERRACCIANO L, TORNILLO L et al. Expression of voltage-gated potassium channels in human and mouse colonic carcinoma. Clin Cancer RES 2007; 13: 824-831. http://dx.doi. org/10.1158/1078-0432

[23] WADHWA S, WADHWA P, DINDA AK AND GUPTA NP. Differential expression of potassium ion channels in human renal cell carcinoma. Int Urol Nephrol 2009; 41: 251-257. http://dx.doi.org/10.1007/s11255-008-9459-Z 
[24] GAVRILOVA-RUCH O, SCHÖNHERR K, GESSNER G, SCHÖNHERR R, KLAPPERSTÜCK T et al. Effects of imipramine on ion channels and proliferation of IGR1 melanoma cells. J Membr Biol 2002; 188: 137-149. http://dx.doi. org/10.1007/s00232-001-0181-3

[25] PARDO LA, DEL CAMINO D, SÁNCHEZ A, ALVES F, BRÜGGEMANN A et al. Oncogenic potential of EAG K+ channels. EMBO J 1999; 18: 5540-5547. http://dx.doi. org/10.1093/emboj/18.20.5540

[26] AGARWAL JR, GRIESINGER F, STÜHMER W AND PARDO LA. The potassium channel Ether à go-go is a novel prognostic factor with functional relevance in acute myeloid leukemia. Mol Cancer 2010; 9: 18. http://dx.doi.org/10.1186/1476-4598-9-18
[27] ASHER V, KHAN R, WARREN A, SHAW R, SCHALKWYK $\mathrm{GV}$ et al. The Eag potassium channel as a new prognostic marker in ovarian cancer. Diagn Pathol 2010; 5: 78. http:// dx.doi.org/10.1186/1746-1596-5-78

[28] CAMACHO J. Ether à go-go potassium channels and cancer. Cancer Lett 2006; 233: 1-9. http://dx.doi.org/10.1016/ j.canlet.2005.02.016

[29] ASHER V, SOWTER H, SHAW R, BALI A and KHAN R. Eag and HERG potassium channels as novel therapeutic targets in cancer. World J Surg Oncol 2010; 8: 113. http://dx.doi. org/10.1186/1477-7819-8-113 